\title{
MENSTRUASI DAN OSTEOPOROSIS (FAKTOR YANG MEMPENGARUHI AKTIVITAS JASMANI WANITA)
}

Oleh: Soni Nopembri

Dosen Jurusan Pendidikan Olahraga dan Rekreasi FIK UNY

\section{Abstrak}

Tulisan ini berawal dari kenyataan bahwa keterlibatan wanita dalam olahraga kian hari semakin tinggi. Perubahan secara fisiologis yang khas dalam diri seorang wanita menjadi suatu bidang kajian yang menarik bagi para peneliti di bidang sport medicine. Wanita yang terlibat dalam olahraga secara intensif harus mendapatkan perhatian agar mereka dapat menjaga kesehatan tubunya tanpa mengalami gangguan yang berarti dari perubahan fisiologis yang terjadi. Laki-laki dan perempuan berbeda secara anatomis dan fisiologis. Menstruasi merupakan salah satu bentuk siklus rutin yang terjadi dalam tubuh wanita dan seringkali menjadi faktor penentu kondisi fisiologis maupun psikologis seorang wanita terutama berhubungan dengan keterlibatannya dalam olahraga. Menstruasi dapat mempengaruhi aktivitas jasmani wanita dan sebaliknya aktivitas jasmani akan mempengaruhi skilus menstruasi wanita. Osteoporosis terjadi lebih cepat pada wanita dibandingkan pria. Osteoporosis juga mempengaruhi seorang wanita untuk beraktivitas jasmani dan sebaliknya melakukan banyak aktivitas jasmani akan memperlambat proses 
osteoporosis pada wanita. Wanita perlu menyadari bahwa dirinya harus menikmati aktivitas jasmani dengan tingkat kesehatan yang

$\begin{aligned} & \text { Kata kunci: } \text { Menstruasi, Osteoporosis, Olahraga, dan } \\ & \text { Wanita. }\end{aligned}$

Keterlibatan wanita pada olahraga sudah menjadi sesuatu hal yang tidak "tabu" lagi dewasa ini. Seiring dengan arus globalisasi yang terus mengalir, gender memberikan dukungan kuat pada wanita untuk masuk dalam bidang yang sudah dianggap maskulin itu. Selain itu, meningkatnya kesadaran akan perlunya kesehatan dan kebugaran jasmani mendorong para wanita untuk ambil bagian dalam berbagai bentuk aktivitas jasmani, termasuk olahraga. Begitu perkasanya para pria dipentas olahraga prestasi telah membangkitkan kaum wanita untuk ikut berprestasi dalam bidang tersebut. Hartono (1999: 225) menyebutkan bahwa pertandingan olahraga yang dilakukan wanita di Amerika terjadi setelah adanya revolusi jerman tahun 1849 sampai tahun 1910, kemudian tahun 1920 terjadi pertentangan yang berakibat pada berakhirnya partisipasi wanita dalam olahraga dan tahun 1950-an muncul trend yang memulai kembali keterlibatan wanita dalam olahraga.

Keterlibatan wanita dalam olahraga sekarang bukan hanya berperan sebagai penonton yang hanya memberikan

MEDIKORA Vol.III, No 2, Oktober 2007: 232-245 
dukungan diluar lapangan tetapi wanita telah terlibat langsung menjadi pelaku olahraga itu sendiri. Banyaknya wanita yang terlibat dalam olahraga telah mendorong para peneliti untuk menyelidiki berbagai pengaruh olahraga terhadap jasmani, rohani, maupun sosial wanita. Satu hal yang perlu ditekankan dalam hubungannya dengan makalah ini adalah adanya perubahan biologis yang khas pada wanita. Hal inilah yang membedakan secara hakiki wanita dan pria. Perubahan biologis ini seringkali dianalogikan dengan siklus menstruasi dan reproduksi.

Satu hal yang paling penting adalah meyakinkan bahwa atlit wanita dapat mencapai puncak penampilan fisik, sambil terus menikmati kesehatannya yang baik (Kartinah, Komariah, Giriwijoyo, 2006:177). Artinya bahwa wanita yang terlibat dalam aktivitas jasmani yang berat (olahraga) bisa mencapai puncak prestasi dengan tanpa mengalami kelainan perubahan fungsi tubuhnya (fisiologis). Selain itu diharapkan juga tingkat kesehatan atlit wanita berjalan dengan normal, dalam hal ini adalah siklus menstruasi dan reproduksi. Seberapa tinggi prestasi yang dicapai seorang wanita dalam olahraga tidak akan menghilangkan kodrat yang sudah tersirat dalam fungsi tubuhnya. wanita akan mengalami 
menstruasi dan akan mengalami proses reproduksi yang berhubungan dengan melahirkan.

\section{PERBEDAAN FISIK PRIA DAN WANITA}

Pria dan wanita dapat kita bedakan dari segi fisik, baik secara anatomis maupun secara fisiologis (fungsi tubuh). Perbedaan anatomi ini menyebabkan pria lebih mampu melakukan aktivitas jasmani dan olahraga yarig memerlukan kekuatan dan dimensi lain yang lebih besar (Kartinah, Komariah, Giriwijoyo, 2006: 177). Secara fisik, pria dewasa rata-rata 7 - $10 \%$ lebih besar daripada wanita. Perbedaan ukuran itu sangat kecil terlihat pada anak-anak sampai usia pubertas. Velle menjelaskan bahwa akivitas jasmani pria yang lebih tinggi karena pengaruh hormon di dalam otak selama perkembangan janin (Sutresna, 1999:259). Pengaruh hormon testoteron mengakibatkan pria tumbuh lebih tinggi, gelang bahu yang lebih luas, panggul lebih sempit dan tungkai lebih panjang. Sedangkan pengaruh hormon estrogen mengkibatkan wanita berkembang dengan bahu yang lebih sempit, panggul yang lebih luas relatif terhadap tinggi badannya dan "carrying angle" yang lebih besar pada sendi siku. Pada wanita terjadi penimbunan lemak selama masa pubertas, sedangkan pada pria terjadi perkembangan otot.

MEDIKORA Vol.III, No 2, Oktober 2007: 232-245 
Sehingga wanita dewasa mempunyai lemak sekitar dua kali lebih besar dari pada pria. Pria mempunyai darah yang kuranglebih satu liter lebih banyak dari pada wanita. Selain itu dimensi jantung pada pria lebih besar sehingga volume sedenyut lebih besar, volume paru-paru pria lebih besar $10 \%$ dari pada wanita. Wanita mempunyai denyut nadi istirahat yang lebih sedikit tinggi dengan Denyut Nadi Maksimal sesuai umur sama.

Berbagai penelitian lebih banyak melihat bahwa wanita mempunyai kapasitas kerja yang relatif buruk, sehingga menjadi pembatas bagi wanita terlibat dalam olahraga. Tetapi pada wanita dan pria yang terlatih tidak terlihat perbedaan secara fisiologis. Latihan kekuatan yang sistemik dapat meningkatkan diamater serabut otot dan massa total ototnya. Kandungan lemak dalam tubuh menurun sebagai respon terhadap latihan. Banyak atlit wanita dalam olahraga yang memerlukan daya tahan mempunyai kandungan lemak yang sedikit. Lemak tubuh yang tinggi menjadi hambatan bagi kegiatan fisik yang bersifat weight bearing, tetapi meningkatkan daya apung pada renang.

Pria dan wanita yang melakukan olahraga sama akan memiliki kapasitas aerobik (VO2max) dengan perbedaan yang lebih kecil dari pada sesama jenis kelamin yang melakukan 
olahraga berbeda. Keikutsertaan wanita dalam aktivitas jasmani dan olahraga berdampak positif pada power aerobic mereka łoleh meningkatnya VO2max, Pengambilan Oksigen dan Kapasitas ventilatori. Apalagi, wanita dapat memperoleh kekuatan maksimal melalui peningkatan aktivasi otot, fleksibilitas meningkat yang berkaitan dengan peningkatan luas gerakan dan barangkali peningkatan fungsi kekebalan. Sebetulnya pria mempunyai keuntungan sampai $50 \%$ dalam hal masa tubuh, volume jantung dan darah, dan hemaglobin yang tinggi. Tetapi perbedaan itu sebesar $10 \%$ apabila dinyatakan dalam satuan berat badan. Atlit wanita yang berlatih baik mempunyai kemampuan men-toleransi hipoxia, ketinggian dan stres pana yang sama dengan pria yang terlatih.

Cedera olahraga pada wanita ditemukan sedikit, karena wanita lebih banyak terlibat pada aktivitas jasmani dan olahraga kontak yang tidak berat. Sehingga cedera lebih bersifat sport specific dari pada sex specific. Cedera pada wanita dalam olahraga sebenarnya lebih dikarenakan kekuatan dan kebugaran mereka yang rendah. Cedera atlit yang terlatih juga mempunyai derajat cedera yang sama.

MEDIKORA Vol.III, No 2, Oktober 2007: 232-245 


\section{AKTIVITAS JASMANI DAN MENSTRUASI \\ Pengaruh Menstruasi pada Penampilan Fisik}

Pada umumnya wanita dapat menikmati kegiatan fisik mereka baik bersifat rekreasi maupun kompetisi tanpa terpengaruh oleh pola menstruasi mereka. Gejala-gejala nyeri pada menstruasi (Dysimenorrhoea) dan Sindroma Stress Premenstruasi (PMS) menjadi berkurang sebagai pengaruh dari olahraga yang teratur. Berbagai penelitian belum berhasil menunjukkan pengaruh kuat secara fisiologis olahraga pada kestabilan siklus menstruasi. Banyak wanita beranggapaan mereka mampu tampil dalam olahraga sama baik selama maupun segera sebelum terjadinya menstruasi. Indikasi medis tidak memperlihatkan wanita harus menghentikan aktivitas fisiknya selama menstruasi. Banyak cara alternatif untuk menguranngi dysmenorrhoea pada atlit wanita, seperti diobati secara efektif dengan pemberian obat anti inflamasi non-steroid, diatur dengan konstrasepsi oral, memperpendek siklus dengan pemberian obat secara dini.

Amenorrhoea atlit dimaksudkan untuk mendeskripsikan berhentinya menstruasi yang dialami beberapa atlit selama masa latihan dan kompetisi berat. Perubahan menstruasi dapat berupa berkurangnya jumlah menstruasi pertahun (oligomenorrhoea) atau sama sekali 
tidak ada menstruasi (amenorrhoea). Hasil penelitian menunjukkan bahwa disfungsi menstruasi bervariasi menurut tingkat usaha fisik selama latihan dan kompetisi. Hal itu juga menunjukkan juga bahwa penampilan yang baik dalam olahraga secara relatif tidak dapat dipengaruhi oleh menstruasi. Ada atlit wanita yang mempunyai penampilan baik saat menstruasi dan ada juga atlit wanita yang menganggap bahwa penampilan buruknya diakibatkan oleh pengaruh menstruasi yang negarif.

\section{Pengaruh Aktivitas Fisik pada Fungsi Menstruasi}

Perubahan siklus menstruasi pada atlit wanita sulit diketahui oleh karena munculnya gangguan menstruasi, dari luteal sampai amenorrhoea. Secara definitif, klasifikasi kejadian menstruasi sebagai berikut: (1) Eumenorrhoea yaitu siklus menstruasi yang teratur dengan interval peridarahan yang terjadi antara 21 - 35 hari, (2) Oligomenorrhoea yaitu bila menstruasi terjadi dengan interval lebih antara 35 - 90 hari, (3) Amenorrhoea yaitu bila dalam kurun waktu 3 bulan berturut-turut tidak terjadi menstruasi, atau menstruasi terjadi tidak lebih dari $3 \mathrm{x}$ dalam setahun.

Perubahan menstruasi paling umum dijumpai pada pelari jarak jauh, penari dan pesenam dan sedikit pada pembala sepeda dan perenang. Data yang diperoleh dari

MEDIKORA Vol.III, No 2, Oktober 2007: 232-245 
sejumlah besar wanita yang berolahraga di lapangan sangatlah terbatas. The American College of Sport Medicine (ACSM) melaporkan bahwa sekitar sepertiga pelari jarak jauh wanita (12 - 45 tahun), mengalami amenorrhoea atau oligomenorrhoea (Hartono, 1999: 226). Penelitian yang dilakukan oleh Dale et al (Hartono, 1999: 226) menunjukan incidence disfungsi menstruasi pada atlit mulai dari $0 \%-50$ $\%$. Rougier dan Linquettte menemukan pengaruh yang bervariasi dari olahraga terhadap siklus menstruasi pada mahasiswa olahraga, demikian juga Kabisch yang mengevaluasi atlit jerman, menemukan sedikit kejadian amenorrhoea (Hartono, 1999: 226). Sebaliknya, Erdelyi, yang meneliti atlit dunia dan Zhanel, yang meneliti atlit anggar, menemukan 10 - $12 \%$ kejadian disfungsi menstruasi (Hartono, 1999: 226).

Beberapa penelitian menunjukkan bahwa anak perempuan yang mengikuti kegiatan fisik yang maikn meningkat sebelum datangnya menarche akan mengalami penundaan menarche dan terjadinya katidakteraturan menstruasinya. Penelitian Frisch et al menemukan bahwa pada pelari maupun perenang yang belum mengalami menarche, menarche akan terlambat 5 bulan untuk tiap tahun berlatih sebelum menarche. Sebaliknya, Erdely tidak 
menemukan perubahan menarche, tetapi menemukan incidence yang tinggi dari fungsi menstruasi di kemudian harinya pada mereka yang melakukan pelatihan atletik premenarche secara intensif bila dibandingkan dengan populasi umum di Hungaria (Hartono, 1999:226). Keterlambatan menarche dan disfungsi menstruasi yang mengikutinya, juga ditemukan pada atlit balet yang melakukan pelatihan premenarche yang intensif dan bermotivasi tinggi untuk mempertahankan berat badan ringan (Frisch et al dalam Hartono, 1999: 226). Ada faktorfaktor yang berhubungan dengan perubahan siklus menstruasi, yaitu seperti pada tabel berikut ini.

\begin{tabular}{|l|l|}
\hline Menstruasi yang teratur & $\begin{array}{l}\text { Menstruasi yang tidak } \\
\text { teratur }\end{array}$ \\
\hline $\begin{array}{l}\text { Kematangan poros } \\
\text { reproduksi }\end{array}$ & Usia muda (youth) \\
\hline Siklus ovulasi yang mapan & Nulliparitas \\
\hline Usia dewasa & Penurunan berat badan \\
\hline Ibu-ibu (motherhood) & Penurunan lemak tubuh \\
\hline Peningkatan berat badan & Tata-gizi rendah kalori dosis \\
\hline Peningkatan lemak tubuh & $\begin{array}{l}\text { Latihan dengan } \\
\text { intensitas tinggi }\end{array}$ \\
\hline $\begin{array}{l}\text { Peningkatan aktivitas } \\
\text { berangsur }\end{array}$ & Beban kerja meningkat cepat \\
\hline $\begin{array}{l}\text { Latihan dengan intensitas } \\
\text { rendah }\end{array}$ & Stress psikologik \\
\hline
\end{tabular}

Tabel 1. Faktor-faktor yang mempengaruhi Menstruasi. Kartinah, Komariah, Giriwijoyo (2006:186).

MEDIKORA Vol.III, No 2, Oktober 2007: 232-245 


\section{OSTEOPOROSIS PADA WANITA}

Salah satu penyakit yang diidap para wanita adalah osteoporosis. osteoporosis merupakan penyakit yang menyerang tulang. Terjadinya osteoporosis akan dapat mengakibatkan resiko patah tulang. Hilangnya mineral tulang akan mengakibatkan osteoporosis. Gejala kliniknya meliputi meningkatnya kejadian fraktur kerangka (terutama pada spina, pergelangan tangan dan paha), kyposis tulang spina akibat fraktur kompresi vertebra spontan disertai nyeri punggung yang tiba-tiba. Kejadian ini menimpa 1 dari tiap 5 wanita berusia di atas 60 tahun, dan kejadian pada wanita adalah 4 kali lebih banyak dari pada pria. Hal ini disebabkan karena puncak massa tulang yang dicapainya lebih rendah dan kehilangan mineral tulang lebih cepat setelah menopause (Kartinah, Komariah, Giriwijoyo, 2006:194).

Masa tulang setiap individu ditentukan oleh beberapa faktor, yaitu: (1) faktor genetik lebih cenderung oleh adanya osteoporosis dalam keluarga, (2) faktor lingkungan meliputi kegiatan fisik, tata-gizi, pengaruh buruk, merokok, kafein dan alkohol. Kurangnya aktivitas jasmani dan ketiadaan gaya berat mengakibatkan cepat hilangnya massa tulang dan keseimbangan kalsium yang negarif. Olahraga melalui latihan yang teratur dapat meningkatkan massa tulang dan lebih 
sedikit kehilangan mineral tulang (Kartinah, Komariah, Giriwijoyo, 2006:195), (3) faktor Hormonal, androgen meningkatkan massa tulang pada pria dan oestrogen dan juga progesteron merupakan faktor penting bagi peningkatan massa tulang pada wanita.

Cara satu-satunya pengelolaan osteoporosis yang paling masuk akal adalah pencegahan. Semua wanita harus didorong untuk melakukan olahraga secara teratur sepanjang hidupnya, oleh karena massa tulang berkorelasi positif dengan kekuatan otot dan berat badan. Aktivitas jasmani yang dilakukan secara teratur dapat membantu mempertahankan kesehatan tulang, otot-otot, dan sendi. Semua wanita segala umur akan mendapatkan manfaat dari aktivitas jasmani intensitas sedang yang dilakukan setiap hari (seperti 30 menit jalan cepat) atau aktivitas yang sedikit lebih berat dalam waktu singkat (seperti 15 - 20 menit joging). Selain itu rekomendasi umum yang hendaknya dicapaii adalah mendapatkan pengaruh altihan dengan sedikitnya 3 hari latihan beban dalam seminggu, yang melibatkan otot-otot besar selama 30 menit per kali latihan (Kartinah, Komariah, Giriwijoyo, 2006:198).

Selain aktivitas jasmani dan olahraga yang harus dilakukan para wanita, juga harus dipenuhinya kecukupan

MEDIKORA Vol.III, No 2, Oktober 2007: 232-245 
kalsium sepanjang hidup, khususnya dimasa pubertas. Terapi hormonal selama masa menopause masih tetap kontroversi. Selain itu dosis estrogen rendah selama 3 minggu dikombinasikan dengan progesteron merupakan regimen yang praktis (Kartinah, Komariah, Giriwijoyo, 2006:198). Gejala osteoporosis dapat juga diobati dengan menggunakan suplemen flourida $(\mathrm{F})$, vitamin $\mathrm{D}$, dan calcitonin dibawah supervisi dokter.

\section{KESIMPULAN}

Pria dan wanita secara kodrati diberikan perbedaan secara anatomis dan juga fisiologis. Perbedaan ini menjadi titik awal kurangnya keterlibatan wanita dalam akvititas jasmani dan olahraga. Setelah adanya pertandingan olahraga yang dilakukan oleh para wanita, keterlibatan wanita dalam olahraga sampai sekarang terus meningkat meskipun sempat terjadi pertentangan. Keterlibatan wanita dalam berbagai bentuk aktivitas jasmani dan olahraga seringkali dihubungkan dengan siklus menstruasi dan reproduksi yang dianggap sebagai pembatas keterlibatannya. Berbagai penelitian dilakukan untuk melihat pengaruh dari siklus menstruasi terhadap prestasi penampilan atlit, begitupun sebaliknya pengaruh olahraga terhadap siklus menstruasi 
wanita. Semua itu sebenarnya berpangkal pada wanita diharapkan dapat menikmati akvititas jasmani dan olahraga yang dilakkukannya dengan tingkat kesehatan yang normal. Pencegahan terhadap terjadinya osteoporosis merupakan salah satu manfaat dari melakukan aktivitas jasmani dan olahraga yang teratur.

\section{Daftar Pustaka}

Hartono, S. 1999. Sebuah Reviu Mengenai Masalah Wanita dan Olahraga. Dalam Perkembangan Olahraga Terkini: Kajian Para Pakar. Page 225-243. Jakarta. PT. Raja Grafindo Persada.

Sutresna, N. 1999. Wanita dan Olahraga Fenomena Sosial. Perkembangan Olahraga Terkini: Kajian Para Pakar. Page 253-267. Jakarta. PT. Raja Grafindo Persada.

Kartinah, N. T., Komariyah, L., Giriwijoyo, S. 2006. Sport Medicine. Fakultas Pendidikan Olahraga dan Kesehatan Universitas Pendidikan Indonesia.

The President's Council on Physical Fitness and Sports Report. 1997. Physical Activity \& Sport in the Lives of Girls. The Center for Research on Girls \& Women in Sport University of Minnesota.

The President's Council on Physical Fitness and Sports. 2004. Physical Activity and Health Women. A Report of the Surgeon General. Centers for Disease Control and Prevention. U.S. DEPARTMENT OF HEALTH AND HUMAN SERVICES

MEDIKORA Vol.III, No 2, Oktober 2007: 232-245 